$\begin{array}{ll}\text { NAMA } & : \text { MUHAMMAD MUHIB } \\ \text { NIM } & : 90100118010 \\ \text { KELAS } & : \text { EKONOMI ISLAM A }\end{array}$

\title{
TOKOH PEMIKIR MERKANTILISME
}

Konsep ekonomi merkantilisme muncul sekitar abad ke-18 dengan pandangan ekonomi yang berkaitan dengan konsep kesejahteraan negara. Konsep pemikirannya mengasumsikan bahwa suatu negara yang ingin lebih maju harus menjalin kerjasama perdagangan dengan negara lain, kemudian dari perdagangan luar negeri akan terjadi surplus perdagangan luar negeri berupa emas dan perak. Karena pandangannya tentang perdagangan luar negeri, kelompok pedagang memiliki peran penting dalam masyarakat. (Munif, 2015)

Dari sudut pandang sejarah, menurut Robert (2008) merkantilisme adalah yang tertua dan dapat dianggap sebagai teori penting dalam ekonomi internasional, karena berkontribusi pada gagasan sistem "koersif" sebagai dasar bagi semua negara-bangsa. Perkembangan merkantilisme klasik terkait dengan kemunculan negara-bangsa modern di Eropa pada abad 15-18. Kekayaan dan kekuasaan merupakan bagian tak terpisahkan dari proses membangun bangsa dan negara yang sejahtera dan aman. Artinya kekayaan dan kekuasaan berputar dalam lingkaran setan sehingga tujuan akhirnya adalah menciptakan kekayaan, dan ini pada gilirannya meningkatkan kekuasaan. (Erna, 2017) Colbert berpendapat bahwa hanya konstitusi harta perang utama yang dapat melindungi kekayaan nasional, serta kemampuan untuk meneror dan mendominasi suatu negara melalui kekuatan militernya.. (Jacques, 2008)

\section{Tokoh Pemikir Paham Merkantilisme}

\section{1) Jean Bodin (1530-1596)}

Jean Bowden (1530-1596) lahir di Angers, Prancis dan meninggal pada Juni 1596 di Laon. Bowden adalah seorang filsuf politik Prancis yang mengekspos prinsip-prinsip pemerintahan yang sangat berpengaruh dan stabil di Eropa abad pertengahan untuk menawarkan solusi kepada negara-negara yang menggunakan sistem terpusat. Bowden mengatakan dalam Reponse Aux Paradoxes de Malestroit (1568) 60, bahwa kenaikan harga 
komoditas umumnya disebabkan oleh 5 faktor, yaitu: (1) Peningkatan logam mulia seperti perak dan emas. (2) Melakukan monopoli global swasta dan peran negara. (3) Jumlah barang dalam negeri menjadi langka karena sebagian produksi diekspor. (4) Gaya hidup mewah di kalangan bangsawan dan bangsawan. (5) Koin disusutkan karena kandungan karatnya yang rendah atau karena proses di dalamnya.

\section{2) Thomas Mun (1571 - 1641)}

Thomas Mun adalah seorang saudagar kaya dari Inggris yang sering menulis tentang perdagangan luar negeri. Moon adalah anggota Masyarakat Ekonomi dan Bisnis Inggris (abad ke-17), yang paling terkenal dan paling dihormati dalam ensiklopedia "Mercantilian" Inggris. Kelompok tersebut menyarankan agar Inggris menggunakan surplus perdagangan untuk mengembangkan negara secara ekonomi. Dalam buku pertamanya, A Discourse of Trade, From England to the East Indies (1621), Mun tidak menganggapnya sebagai doktrin perdagangan yang hebat. "Negara akan sejahtera seperti keluarga, dengan menabung dan menabung lebih dari yang mereka belanjakan. Begitu pula, negara dan keluarga akan menjadi miskin jika menghabiskan banyak uang,"

\section{3) Jean Baptiste Colbert (1619 - 1683)}

Jean-Baptiste Colbert lahir di Reims, Prancis, pada 29 Agustus 1619, dan meninggal pada 6 September 1683. Colbert bukanlah seorang ekonom, tetapi seorang pejabat negara Prancis dengan posisi Perdana Menteri Ekonomi dan Keuangan di pemerintahan Raja Louis XIV. . Colbert menjamin hak monopoli yang diberikan kepada perusahaan guna mendorong munculnya perusahaan baru, terutama untuk perdagangan antar negara. Ini merangsang penemuan baru dan membangun industri eksperimental. Ia juga mendorong perkembangan ilmu pengetahuan dengan mendirikan akademi dan perpustakaan serta memberikan subsidi kepada setiap sektor ekonomi.

\section{4) Sir William Petty (1623 - 1687)}

Sir William Petty lahir pada 26 Mei 1623 dan meninggal pada 16 Desember 1687. Ia adalah seorang ekonom, ilmuwan, filsuf, Anggota Parlemen, dan anggota piagam Royal Society. Menurutnya, negara perlu mengatur jumlah uang yang beredar, karena menurutnya 
kebutuhan uang dalam jumlah yang cukup, jika lebih atau kurang dari yang dibutuhkan dapat menimbulkan masalah. Harga uang adalah kegunaan modal, jadi semakin besar jumlah uang beredar, semakin rendah bunga modal, semakin banyak aktivitas bisnis yang akan didorong.(Faruq \& Mulyanto, 2017)

\section{DAFTAR PUSTAKA}

Fontanel, J., Hebert, J., \& Samson, I. "The Birth Of The Political Economy Or The Economy In The Heart Of Politics: Mercantilism”. Defence and Peace Economics, 19(5), (2008): 331-338.

Faruq, U. Al, \& Mulyanto, E. (2017). Sejarah Teori-Teori Ekonomi (Issue 1). 
Utama, I., Ekonomi, D., Global, P., Merkantilisme, A., \& Liberalisme, D. (n.d.). Ideologi Utama Dalam Ekonomi Politik Global Antara Merkantilisme Dan Liberalisme.

Munif, Nasrulloh Ali. "Sistem Ekonomi Islam: Dialektika Antara Thesis, Antitesis dan Plagiatis." IAIN Tulungagung Research Collections 2.1 (2015): 319-348. 